

\title{
DISTRIBUTED LEADERSHIP AN INSTRUMENT FOR SCHOOL IMPROVEMENT: THE STUDY OF PUBLIC SENIOR HIGH SCHOOLS IN GHANA
}

\author{
Dandy George Dampson (PhD) \\ (dgdampson@gmail.com) \\ Department of Psychology and Education \\ University of Education, Winneba \\ $\&$ \\ Felicia Mansa Havor \\ University of Education, Winneba \\ $\&$ \\ Prince Laryea \\ Institute of Distance and e-Learning \\ University of Education, Winneba
}

The purpose of the study was to investigate the influence of distributed leadership in Public Senior High Schools (SHS) with regard to school improvement. Using the Explanatory Sequential Mixed-Method design, 92 teachers and 4 head masters and 4 assistant head masters were randomly and census sampled. Three research questions were formulated and were analysed using simple percentages, mean and constant comparative thematic approach. The study revealed that generally head and assistant head masters and teachers recognize the practice of distributed leadership style in the SHS, that is they perceive distributed leadership as a shared leadership where everyone is considered as a leader and given leadership opportunities. The findings further revealed that traditional and rigid leadership structure, lack of shared responsibility amongst teachers, leaders fear to involve teachers were the dominant challenges of distributed leadership in the study area. The study concluded that majority of the head masters, assistant head masters and teachers are currently practicing the distributed leadership since the success of distributed leadership depends on whether the leadership is willing to relinquish power, and the extent to which staff embrace the opportunity to lead. Based on the findings and conclusion drawn for the study, it is recommended that leadership in public SHS develops strategies that allow all teachers who are capable and willing to get an opportunity to lead certain areas of the school.

Keywords: Leadership, Distributed leadership, Heads, Teachers, Public Senior High School, Improvement 


\section{Introduction}

Leadership is a complex phenomenon that exists in any organization where the need of inspiring and influencing members of the given organization. Gronn (2002) states leadership as a process whereby an individual influences a group of individuals to achieve a common goal in the organization. Universities as educational organization adapt and apply different types of leadership approach that fits the existing context to achieve their own mission and goals.

The quality of leadership determines the motivation of teachers and the quality of teaching in the classroom (Sergiovanni, 2001). Although there has been large proliferation of leadership theories and styles, the majority of studies are largely concerned with the leadership capabilities of just one person (Spillane, \& Healey, 2010). Traditionally school leadership has been that of the top-down approach where the leader leads, makes key decisions, motivates, and inspires. In contrast to traditional scholars of leadership who pay attention to an individual managing hierarchical structure, other researchers have generated evidence that the school principal does not have a monopoly on school leadership (Muijs \& Harris, 2003).

Styles of leadership which encourage leaders to share responsibilities and authority have been the subject of much recent interest. This alternative involves thinking of leadership in terms of activities and interactions that are distributed across multiple people and situations (Camburn, Rowan, \& Taylor, 2004; Spillane, 2006). The bulk of school leadership research has made light of its distributed character (Wallace, 2001). Educators are frequently faced with the challenges of politics, hostility, selfishness, and violence; in order to overcome these obstacles requires teamwork, motivation, empowerment, and communication. Therefore, it is unwise to think that head of a school is the only one providing leadership for school improvement thus presenting a compelling argument for re-defining leadership away from role-based conceptions and towards distributive views (Spillane, 2006).

\section{The Notion of Distributed Leadership}

Given the fact that distributed leadership as an area of scientific inquiry is still in its infancy, a common understanding of distributed leadership has yet to be conceived of (Bennett et al. 2003; Day et al. 2000). Some authors use the term shared leadership (e.g., Pearce \& Sims 2002; Pearce 2004) while others employ the term distributed leadership (e.g., Gronn 2002). At this point, there seems to be no clear conceptual differences between these approaches, and different authors use them interchangeably (e.g., Day et al. 2000).

Besides the different terms employed, different authors diverge in their conceptualizations of distributed leadership on various grounds, including the scope of the network of participating agents in the leadership process. Some authors have focused on a single team or group of people as their unit of analysis (e.g., Brown and Hosking Pearce 2004), while others have taken a more open-systems approach, taking the whole organization and even constituencies beyond the organizational boundaries as their unit of analysis (e.g., Spillane et al. 2004). However, despite these differences most authors agree upon two principles as underpinning the concept of distributed leadership: firstly, leadership is a shared influence process to which several individuals contribute and secondly, leadership arises from the interactions of diverse individuals, which together form a group, or network in which essential expertise is a dispersed quality.

The importance given to the idea of "leadership" has grown enormously in virtually all sectors, and education has been no exception (Harris, 2004). In addition, distributed 
leadership is a developing process involving different forms of leadership practices. MacBeath (2005) interviewed and shadowed headteachers of schools, which exemplified distributed leadership and were interested in becoming distributive in their practices in order to explore what "distributed leadership" means in the day-to-day life in schools in the United Kingdom. The research findings suggest that distributed leadership is a developing process. Under the developing process, six categories of distributed leadership practice were defined: distribution formally, pragmatically, strategically, incrementally, opportunistically, and culturally, and each of them represents a different way of thinking about leadership and exemplifies differing processes of distribution.

The concept of teachers working together to improve their teaching practices is a move away from the isolation and individualism of teaching as highlighted by authors such as Fullan (1993) and Spillane (2001) and, in an era of rapid and significant change, it was essential that teachers would work together rather than separately. Teamwork was one of the structural changes that supported the introduction of new curriculum content and methodologies. Depending on the particular leadership task, school leaders' knowledge and expertise might best be explored at the group or collective level rather than at the individual leader's level (Spillane, Halverson \& Diamond 2001).

In the school context this interdependence exists between the teacher, the students they teach, their subject department and the overall school culture and context. Spillane and Diamond (2007) explains the idea further by detailing three types of co-leadership practice; collaborative, collective and coordinated.

a. Collaborative leadership distribution is carried out by multiple leaders working together at one time and place.

b. Collective leadership distribution occurs when the work of leaders is performed separately but is interdependent, for example, an assistant headmaster/headmistress making a number of visits to classrooms, giving formative evaluations and the headmaster/headmistress making the formal visit and giving summative evaluation.

c. Coordinated leadership distribution refers to leadership routines that are carried out in a sequence, for example, using data from standardized assessments to influence instruction. A series of steps is required from the initial administering of the tests, to analysing results to presenting information in an appropriate format for discussion at faculty meetings.

A distributed perspective provides a framework for diagnosis and design work. School staffs are key agents in this work (Spillane, 2008). Perhaps one of the major contributions of Spillane's work is that he provides us with the vocabulary and the tools to explore leadership in schools. The distributed leadership perspective is a framework that focuses on teaching and learning and plan for improvement.

\section{Challenges of Distributed leadership}

The distributed leadership movement, is a call for leadership to be shared throughout the organisation in a more democratic fashion; the fundamental premise of the concept of distributed leadership is that leadership activities should not be accreted into the hands of a sole individual but, on the contrary, they should be shared between a number of people in an organisation or team (Mayrowetz 2008). The questions asked is, however, whose interests are being served by particular distributions? Are all distributions intended to enhance teaching and learning or enhance school improvement? It is possible that distributed leadership could support the abuse of power (Maxcy \& Nguyen 2006 in Mayrowetz 2008). 
Teachers can become overstressed by shared decision-making and the benefits of participation do not necessarily accrue to better teaching practice or to the benefit of the school as a whole, especially if teachers and organisational goals are not well aligned (Mayrowetz 2008). While some advantages and benefits have been outlined, there are also risks that distributing leadership will not add to school improvement.

Timperley (2005) concluded that distributing leadership is a risky business and may result in the distribution of incompetence. Harris (2004) outlines some additional difficulties. She recognizes that structural and cultural barriers operate within schools, which could make it very difficult for some teachers to show leadership. Jockeying for power positions in a school can create a climate, which is not conducive to, for example, young teachers expressing their opinion, especially if it differs from the traditional or prevailing opinion. Such action could be perceived as a threat to the status quo. Teachers are usually very aware of the micro politics within a school perhaps more so than a principal and therefore display wise caution: Teachers placed in positions that bear titles and resources of leadership display a caution towards their colleagues that is both poignant and eminently sensible (Weiss \& Cambone 1994). It is understandable that teachers who are used to working with their colleagues as friends and equals would be apprehensive about the expectations of them, particularly by the headmaster/headmistress, when they are placed in a leadership role. This is especially evident in the Irish context where collegiality is highly valued, and sometimes misunderstood. Finally, in a climate of accountability, headmasters/headmistress may be less willing to relinquish power as it might leave them vulnerable due to lack of direct control. This may be particularly true in relation to financial, legal and human resource issues as well as the educational operation of the school (OECD 2008).

\section{Distributed leadership and School Improvement}

Research by Silns and Mulford (2002) has shown that student outcomes are more likely to improve when leadership sources are distributed throughout the school community and when teachers are empowered in areas of expertise. Such an emphasis on decentralized leadership informs the increasing focus on the role of teacher leadership and the development of the contribution of teachers in making decisions about the approaches to educating students (Anderson, 2004). From a distributed leadership perspective, effective principals do not just string together a series of individual actions, but also systematically distribute leadership by building it into the fabric of school life (Spillane, 2006).

The headmaster/headmistress sets the formal conditions to support and nurture collaborative learning (Hopkins \& Jackson 2002; Harris \& Lambert 2003). This may include setting up and maintaining structures such as teams and committees as well as adhoc groups to address specific issues from time to time. The conditions include time and resources but may also extend beyond these to professional development that enhances teachers' abilities to work effectively together.

In what appears to be a resistance to the culture of accountability and external controls, the OECD report (2008) suggests that school leaders can make a difference to school and student performance if they are granted autonomy to make important decisions. However, unless they have the capacity, motivation and support to make use of their autonomy to engage in practices that are most conducive to improved learning, it may have little influence on school outcomes (OECD 2008 p.64). Four leadership responsibilities have been consistently identified as improving learning outcomes:-

1. supporting, evaluating and developing teacher quality; 
2. supporting goal-setting, assessment and accountability (including the use of data to improve practice);

3. enhancing strategic financial and human resource management which includes enhancing financial skills and involving leaders in recruiting their teachers;

4. adopting a systemic approach to leadership policy and practice by encouraging collaboration with partners external to the school and by distributing leadership responsibilities (ibid).

The extent to which teachers are empowered to lead such structures and systems and to operate effectively within them will be determined to a considerable extent by the nature of the leadership in the school. When structures and systems become embedded and collaboration and peer learning begin to take off, the culture of the organisation begins to alter and reform. School based research shows that the most important characteristics of the climate are trust, openness and security (Southworth, 2004).

Spillane (2005), state that research on distributed forms of leadership is still at its early stages and the available empirical evidence about it is not abundant. Besides, the characteristics and application of distributed leadership in higher education have not been adequately explored. Similarly, Harris and Spillane (2008), after comprehensive overviews of the literature states that focus has been increasing on distributed leadership in higher education. Yukl (1999), on other research aimed to develop recommendations on how leadership and leadership development can be enhanced, particularly through encouraging collective engagement with the leadership process and then he concludes that academic leaders need to create an environment or context for academics and others to fulfil their potential and interest in their work if leadership and leadership development takes place, as opposed to focusing solely on the traits and capabilities of individual leaders. Therefore, from the aforementioned researches and insights one can easily concludes that distributed leadership play paramount role for the overall, goal/s attainment of second cycle education.

From the ongoing arguments Williams, (2011) opine that leadership within the Ghanaian traditional context is not a new concept. In fact, leadership plays an important part in the diverse and complex social structure of most communities throughout the countries. However, Dampson (2015) argues that tenets of distributed leadership within the Ghanaian educational and schools context is new and conceptually different. In this context school leaders in Ghana are finding it difficult to come to terms with how, when, who and the benefits of distributed leadership to school improvement. Based on the ongoing views the researchers investigated the influence and perceptions of distributed leadership in a Public Senior High School (SHS) in Ghana.

Based on the arguments raised, the following questions were formulated to guide the study.

1. What perceptions are held by teachers, head and assistant head masters regarding the concept of distributed leadership?

2. What challenges are faced by head masters in distributing leadership in Public Senior High Schools?

3. What conditions enable distributed leadership improve Public Senior High Schools? 


\section{Methodology and Materials}

\section{Research Design}

The Explanatory Sequential Mixed Method design was employed to answer the research questions through the quantitative procedures, while qualitative procedures were followed to explain the initial quantitative results. Using this approach offered the researchers adequate opportunity of going into sufficient details to unravel the complexities of the influence of head and assistant head masters distributed leadership in Public SHS with regards to school improvement (Creswell, 2009).

The study consisted of all the 4 SHS in the Ledzokuku Krowor Municipality, head and assistant head masters and teachers of the selected Public Senior High Schools in the municipality.

The census sampling was adopted to select the 4 SHS, 4 head and 4 assistant head masters. Within the 4 SHS, 23 teachers each totalling 93 were randomly sampled to answer questionnaire. Additionally, all the head and assistant head masters were interviewed. However, 3 teachers each from the four schools totalling 12 were also randomly sampled and interviewed.

The instruments used in the study were structured questionnaire and semi-structured interview. The questionnaire were adopted from OECD Teaching and Learning International Survey (TALIS) (2013) and modified to suit the Ghana context. The interview guide was developed from the findings of the questionnaire. Two separate interview schedules were developed and administered to participants (heads and assistant head masters and teachers). The interview schedule further explored the concept of distributed leadership, the challenges and conditions that promote the practice of distributed leadership for school development. The questionnaire was pilot-tested which yield a Cronbach alpha reliability coefficient of 0.76. The questionnaire was analysed using simple percentages and frequencies. However, the interview was classified according to patterns and a description offering explanations about the situation and condition to refine and explain the tabulated the themes that emerged from the transcripts.

\section{Results and Discussions}

Gender distribution for the study constituted 52\% males and $48 \%$ females. The demographics revealed that $75 \%$ the school leadership have been in school headship for over 15 years and more while $25 \%$ had gained 11-15 years of teaching experience. The teaching and leadership experience of head and assistant head masters is crucial for this study because it implies that they have had adequate experience in leadership which enabled them give empirical, accurate and valuable suggestions that enriched the study. With regards to teachers only few $(17.3 \%)$ had been in teaching profession between 1 and 5 years, while majority $(41.3 \%)$ had been in teaching profession for the duration of over 15 years. 


\section{Research Question 1: What perceptions are held by teachers, head and assistant head masters regarding the concept of distributed leadership?}

Table 1: Perception on distributed leadership

\begin{tabular}{|c|c|c|c|c|c|c|c|c|c|c|c|}
\hline \multirow{2}{*}{ Statement } & \multirow{2}{*}{$\frac{\text { SD }}{\mathrm{N}}$} & \multicolumn{2}{|c|}{ D } & \multicolumn{2}{|r|}{$\mathbf{U}$} & \multicolumn{2}{|c|}{$\mathbf{A}$} & \multicolumn{3}{|c|}{ SA } & \multirow[t]{2}{*}{ M } \\
\hline & & $\%$ & $\mathrm{~N}$ & $\%$ & $\mathrm{~N}$ & $\%$ & $\mathrm{~N}$ & $\%$ & $\mathrm{~N}$ & $\%$ & \\
\hline $\begin{array}{l}\text { Distributed leadership is } \\
\text { practiced in the school. }\end{array}$ & 16 & 16 & 6 & 6 & 3 & 3 & 55 & 55 & 20 & 20 & 3.4 \\
\hline $\begin{array}{l}\text { Heads and teachers are decision } \\
\text { makers in the school. }\end{array}$ & 6 & 6 & 10 & 10 & 3 & 3 & 36 & 36 & 45 & 45 & 4.3 \\
\hline $\begin{array}{l}\text { Colleagues recognize others } \\
\text { capabilities in taking leadership } \\
\text { roles }\end{array}$ & 17 & 17 & 7 & 7 & 10 & 10 & 40 & 40 & 26 & 26 & 3.4 \\
\hline $\begin{array}{l}\text { The leadership structure of the } \\
\text { school allow the practice of } \\
\text { distributed leadership }\end{array}$ & 5 & 5 & 6 & 6 & 8 & 8 & 35 & 35 & 46 & 46 & 4.3 \\
\hline $\begin{array}{l}\text { Colleagues willingly take on } \\
\text { additional responsibilities of } \\
\text { decision making }\end{array}$ & 5 & 5 & 9 & 9 & 3 & 3 & 30 & 30 & 53 & 53 & 4.4 \\
\hline $\begin{array}{l}\text { Source: Field data, } 2017 \\
\text { Mean ranges: } 100-1.50 \text { Stro }\end{array}$ & & & & & & & & & & & 3.96 \\
\hline
\end{tabular}

Table 1 indicates the responses of heads and teachers regarding their perceptions of distributed leadership. In analysing the responses, a mean value of 3.4 indicated that heads and teachers agreed to the practice of distributed leadership in their respective schools. Per the mean value of 4.3 , participants strongly agreed that the heads and teachers are decision makers in the school. A mean value of 4.3, also indicate that teachers strongly agreed that the leadership structure of the school allow the practice of distributed leadership.

The interview transcripts revealed that distributed leadership permeated all areas of the school as changes were seen with its practised by leadership in public SHS. The finding of the study further revealed that the old fashion or traditional style of leadership that used to be practised in the study area which made some SHS teachers afraid and timid to take risk are minimized because of the practise distributed leadership in the school. Majority of the teachers interviewed confirmed that they used to be cautious and afraid of getting things wrong and the consequences associated with it. But now they are confident to take risk and not deter about the outcome but rather motivated to do more because distributed leadership provides them opportunity to learn from mistakes. This finding is consistent with William (2011) who argues that school leadership in South Africa who practised distributed leadership found teachers to be timid and afraid to lead but as they kept on practising they became confident and took risk. One male teacher narrated (MT, 2):

Now people are confidently enough to take things on, do things and make decisions for themselves. And know that if they do get it wrong, then it is not going to first of all, look badly on them [sic].

Rather, learn through the mistakes. This builds staff's confidence and foster unification in directing and meeting the goals and vision of the school. 
The situation prevailing in these Senior High Schools exemplifies the perceptions teachers have with regards to the strategic direction and vision of the school as well as the extent of implementation as shared by a female head teacher (FHT, 3):

More people understand what is it we are trying to achieve and why we are trying to achieve it or the reasons why certain things are being done. Therefore, more people understand why they implement strategic policies in a certain way or feel like having input into the overall school ethos. This situation has helped build team work.

Research conducted by Spillane (2001); MacBeath (2005) and Lizotte (2013) are consistent with the findings of this study that distributed leadership is a developing process of teacher leadership where the incorporation of ideas such as teachers working together in teams; taking a variety of responsibilities in the school; discussing practices with colleagues; giving and accepting critiques of their work is very important. Nonetheless, Lizotte (2013) for example hinted that novice teachers are afraid to accept leadership because of failure.

Research Question 2: What challenges are faced by head masters in distributing leadership in Public Senior High Schools?

Table 2: Challenges of distributed leadership

\begin{tabular}{|c|c|c|c|c|c|c|c|c|c|c|c|}
\hline \multirow[t]{2}{*}{ Statements } & \multirow{2}{*}{$\frac{\text { SD }}{N}$} & \multicolumn{2}{|r|}{ D } & \multicolumn{2}{|r|}{$\mathbf{U}$} & \multicolumn{2}{|c|}{$\mathbf{A}$} & \multicolumn{3}{|c|}{ SA } & \multirow[t]{2}{*}{$\mathbf{M}$} \\
\hline & & $\%$ & $\mathrm{~N}$ & $\%$ & $\mathrm{~N}$ & $\%$ & $\mathrm{~N}$ & $\%$ & $\mathrm{~N}$ & $\%$ & \\
\hline Lack of team-work & 11 & 11 & 8 & 8 & 4 & 4 & 44 & 44 & 33 & 33 & 3.2 \\
\hline Lack of communication & 8 & 8 & 13 & 13 & 0 & 0 & 41 & 41 & 38 & 38 & 3.4 \\
\hline $\begin{array}{l}\text { Lack of shared } \\
\text { responsibility amongst } \\
\text { teachers }\end{array}$ & 11 & 11 & 5 & 5 & 1 & 1 & 63 & 63 & 20 & 20 & 3.5 \\
\hline $\begin{array}{l}\text { Traditional and rigid } \\
\text { leadership structure of the } \\
\text { school }\end{array}$ & 9 & 9 & 6 & 6 & 4 & 4 & 27 & 27 & 54 & 54 & 4.0 \\
\hline $\begin{array}{l}\text { Absence of collegial } \\
\text { relationship amongst } \\
\text { academic staff }\end{array}$ & 14 & 14 & 4 & 4 & 0 & 0 & 62 & 62 & 20 & 20 & 3.1 \\
\hline $\begin{array}{l}\text { Loose tie amongst } \\
\text { administration, } \\
\text { departmental heads and } \\
\text { teaching staff }\end{array}$ & 6 & 6 & 17 & 17 & 1 & 1 & 56 & 56 & 20 & 20 & 3.0 \\
\hline $\begin{array}{l}\text { Leaders fear to involve } \\
\text { teachers in decision } \\
\text { making }\end{array}$ & 6 & 6 & 10 & 10 & 3 & 3 & 25 & 25 & 56 & 56 & 4.0 \\
\hline $\begin{array}{l}\text { Unwillingness of teachers } \\
\text { to participate in the } \\
\text { decision making }\end{array}$ & 16 & 16 & 17 & 17 & 0 & & 47 & 47 & 20 & 20 & 3.3 \\
\hline
\end{tabular}

Source: Field data, 2017

Mean of Means $=3.46$

Mean ranges: 1.00 - 1.50 Strongly Disagree; 1.60 - 2.50 Disagree; 2.60 - 3.50 Agree; 3.60 4.00 Strongly Agree 
Interestingly, all the challenges listed in table 2 generated a mean above 3.0 signifying the importance of these challenges to distributed leadership in the study area. However, traditional and rigid leadership school structure and fear of leadership to involve teachers had the highest mean of 4.0. This finding implies that although leadership understands the concept of distributed leadership and put them in practice, they are however still cautious of who to involve in decision-making. It may seem that the only way to ignore distributing leadership is to put in place rigid leadership structures that will deter teachers from accepting responsibilities. These findings were also echoed by some of the teachers through the interview.

A male head teacher (MT, 8) explained:

Sometimes, you can see that some of us teachers want to take up responsibilities but some head masters make it a bit difficult by following rigid rules which makes some of us afraid to accept because of failure.

Another female teacher $(\mathrm{FT}, 4)$ recounted:

I hold the fact that some of the leaders fear for their position because they see some of us being much responsible than them so they will do everything to deter you from accepting leadership, although some teachers themselves see it as too much workload.

These findings are consistent with that of Harris (2004), Timperley (2005) and Mayrowetz (2008) who argued that teachers can become overstressed through distributed leadership. They were however certain that shared decision-making which is a tenet of distributed leadership accrue to better teaching practice which in turn benefit the school as a whole, especially if teachers and organisational goals are not well aligned. Invariability, Jockeying for power positions in a school can create a climate, which is not conducive to, for example, young teachers expressing their opinion, especially if it differs from the traditional or prevailing opinion. Such action could be perceived as a threat to the status quo (Harris, 2004; Timperley, 2005) which can hinder the benefit of distributed leadership in schools. 
Research Question 3: What conditions enable distributed leadership improve Public

Senior High Schools?

Table 3: Conditions of distributed leadership for school improvement

\begin{tabular}{|c|c|c|c|c|c|c|c|c|c|c|c|}
\hline \multirow[t]{2}{*}{ Statements } & \multirow{2}{*}{$\frac{\mathrm{SD}}{\mathrm{N}}$} & \multicolumn{2}{|c|}{ D } & \multicolumn{2}{|c|}{$\mathrm{N}$} & \multicolumn{2}{|c|}{ A } & \multicolumn{3}{|c|}{ SA } & \multirow[t]{2}{*}{$\mathrm{M}$} \\
\hline & & $\%$ & $\mathrm{~N}$ & $\%$ & $\mathrm{~N}$ & $\%$ & $\mathrm{~N}$ & $\%$ & $\mathrm{~N}$ & $\%$ & \\
\hline $\begin{array}{l}\text { Strong collegial relationship } \\
\text { amongst academic staff }\end{array}$ & 11 & 11 & 5 & 5 & 1 & 1 & 63 & 63 & 20 & 20 & 3.5 \\
\hline $\begin{array}{l}\text { Encouraging staff to } \\
\text { participate in the decision } \\
\text { making }\end{array}$ & 9 & 9 & 6 & 6 & 4 & 4 & 27 & 27 & 54 & 54 & 4.0 \\
\hline $\begin{array}{l}\text { Encouraging team work and } \\
\text { shared responsibility }\end{array}$ & 14 & 14 & 4 & 4 & 0 & 0 & 62 & 62 & 20 & 20 & 3.1 \\
\hline $\begin{array}{l}\text { Ensure well-built relation } \\
\text { amongst administration, } \\
\text { department heads and } \\
\text { teaching staff }\end{array}$ & 6 & 6 & 17 & 17 & 1 & 1 & 56 & 56 & 20 & 20 & 3.0 \\
\hline $\begin{array}{l}\text { Creating favourable } \\
\text { condition to facilitated team } \\
\text { leadership and collective } \\
\text { responsibility }\end{array}$ & 6 & 6 & 10 & 10 & 3 & 3 & 25 & 25 & 56 & 56 & 4.0 \\
\hline $\begin{array}{l}\text { Departmental heads to } \\
\text { encourage the involvement } \\
\text { of teachers in decision } \\
\text { making }\end{array}$ & 16 & 16 & 17 & 17 & 0 & & 47 & 47 & 20 & 20 & 3.3 \\
\hline $\begin{array}{l}\text { Oversee leadership structure } \\
\text { to smooth the progress of } \\
\text { distributed leadership }\end{array}$ & 11 & 11 & 5 & 5 & 1 & 1 & 63 & 63 & 20 & 20 & 3.5 \\
\hline
\end{tabular}

Source: Field data, $2017 \quad$ Mean of Means $=3.53$

Mean ranges: 1.00 - 1.50 Strongly Disagree; 1.60 - 2.50 Disagree; 2.60 - 3.50 Agree; 3.60 4.00 Strongly Agree

Table 3 shows that the heads and teachers unanimously agree to all the conditions or responsibilities associated with distributed leadership in school improvement. This means that there are varieties of leadership responsibilities that have been improving school learning outcomes. The researchers deduced from the mean value of 3.5 that heads and teachers were of the view that strong collegial relationship amongst staff as a responsibility of the head improves the performance of the school.

Evidently, with a mean of 4.0, data from the table 3 reveals that participation in decisionmaking and creating favourable conditions were among the key conditions for school improvement where distributed leadership is practised. This implies that the success of distributed leadership in the study area partly rely on these two conditions, although other conditions such as strong collegial relationship, and smooth leadership structure play an important role. In an interview with both head masters and teachers it was echoed that if the Ghanaian educational system is well decentralized distributing leadership will improve schools.

Silns and Mulford (2002) has shown that student outcomes are more likely to improve when leadership sources are distributed throughout the school community and when teachers are empowered in areas of expertise. The OECD report (2008) further suggests that school 
leaders can make a difference to school and student performance if they are granted autonomy to make important decisions with reference to their capacity, motivation and support to engage in practices that are most conducive to improved learning.

Despite evidence from this study which revealed the challenges associated with distributed leadership, both headmasters and teachers in the study area believe that if respect and trust are considered in high esteem by both leaders and followers, the benefits of distributing leadership will be achieved.

\section{Recommendations and Conclusion}

Giving the finding derived from this study, some recommendations were put forward by the researchers for school improvement. We argue that it is important that head masters in the study area develop strategies that allow all teachers who are capable and willing to get an opportunity to lead certain areas of the school even if it is for shorter periods of time. Furthermore, in order to get the full cooperation of the staff, roles must not be 'dumped' onto unwilling teachers. The head master thus has to know the strengths and weaknesses of his/her staff before delegating roles. Teachers in the Municipality should be encouraged by their head masters and mentors to participate in decision making and take-on other responsibilities to ensure school improvement. When teachers are involved, they take responsibility for their actions and in-actions and that could enhance the quality of work the school provides.

Notwithstanding these recommendations, it is evident from the findings of this study that the practice and concept of distributed leadership is prevalent among public Senior High School head masters and teachers within the study area. It is indicative that the success of distributed leadership depends on whether the head teacher is willing to relinquish power, and the extent to which staff embrace the opportunity to lead. From the study it is clear that the desire to encourage staff participation in decision making and the creation of favourable conditions for shared responsibilities, promote the practice of distributed leadership. However, distributed leadership is beset with some challenges due to lack of communication, unwillingness of teachers to participate in decision making and take on other responsibilities. On the other side, student and school outcomes are more likely to improve when leadership responsibilities are distributed throughout the school community. 


\section{References}

Anderson, D. R. (2002). "Avoiding pitfalls when using information-theoretic methods." Journal of Wildlife Management 66:910-6.

Bennett, N., Harvey, J.A., Wise, C. \& Woods, P.A. (2003) Desk study review of distributed leadership. Nottingham, UK: National College for School Leadership/Centre for Educational Policy \& Management.

Brown, M. H., \& Hosking, D. M. (1986). Distributed leadership and skilled performance as successful organization in social movements. Human Relations, 39, 65-79. doi:10.1177/001872678603900104.

Camburn, E., Rowan, B. \& Taylor, J. (2003). Distributed leadership in schools: The case of elementary schools adopting comprehensive school reform models. Michigan: University of Michigan.

Creswell, J. W. (2009). Research design: Qualitative, quantitative and mixed methods approaches. $3^{\text {rd }}$ ed. California: Sage Publications.

Dampson, D. G. (2015) Teacher participation in decision-making in Ghanaian basic schools: a study of some selected basic schools in the Cape Coast Metropolitan area and Mfantseman Municipality in the Central Region of Ghana. Volume1 and 2. Doctoral thesis. The University of Northampton.

Day, C., Harris, A., Hadfield, M., Tolley, H., \& Beresford, J. (2000). Leading schools in times of change. Buckingham, UK: Open University Press.

Fullan, M. (1993). Change forces: Probing the depths of educational reform. London: Falmer Press.

Gronn, P. (2002). The new work of educational leaders. London: Paul Chapman Press.

Harris, A. \& Lambert, L. (2003) Building leadership capacity for school improvement. Milton Keynes: Open University Press.

Harris, A. \& Spillane, J. (2008). Distributed leadership through the looking glass. British Educational Leadership, Management \& Administration Society, 22 (1): 31-34.

Harris, A. (2004). Distributed school leadership: Developing tomorrow's leaders. London: Routledge.

Harris, A., Day, C., Hadfield, M., Hopkins, D., Hargreaves, A., \& Chapman, C. (2004). Effective leadership for school improvement. London: Routledge

Hopkins, D. \& Jackson, D. (2002) 'Building the Capacity for Leading and Learning', in A. Harris, C. Day, M. Hadfield, D. Hopkins, A. Hargreaves and C. Chapman (eds) Effective Leadership for School Improvement. London: Routledge, pp. 84-105.

Lizotte, J. O. (2013). "A qualitative analysis of distributed leadership and teacher perspective of principal leadership effectiveness", unpublished Doctor of Education thesis, Northeastern University, Boston, MA 
Mayrowetz D (2008) Making sense of distributed leadership: Exploring the multiple usages of the concept in the field. Educational Administration Quarterly 44(3): 424-435.

OECD (2008), OECD Annual Report 2008. Retrieved from www.oecd.org/dataoecd/39/19/40556222.pdf

OECD (2013) Teaching and Learning Survey (TALIS) Teacher Questionnaire. National Project Information. Canada.

Pearce, C. L. (2004). The future of leadership: Combining vertical and shared leadership to transform knowledge work. Academy of Management Executive, 19, 47-57.

Sergiovanni, T. (2001). Leadership: What's in it for schools? London: Routledge Falmer.

Silins, H., \& Mulford, B. (2002) Leadership and school results second international handbook of educational leadership and administration. Netherlands: Kluwer Press.

Southworth, G. (2004), Primary school leadership in context: Leading small, medium and large-sized primary schools. London: Routledge Falmer

Spillane J. P. (2008) Distributed leadership. San Francisco: Jossey Bass.

Spillane J. P. \& Diamond J. B. (2007) Distributed leadership in practice. New York, NY: Teachers College Press

Spillane, J. P. \& Healey, K. (2010). Conceptualizing school leadership and management from a distributed perspective. The Elementary School Journal. 111 (2): 253-281.

Spillane, J. P. (2006). Distributed Leadership. San Francisco: Jossey Bass.

Spillane, J. P., Halverson, R., \& Diamond, J. B. (2001). Investigating school leadership practice: A distributed perspective. Educational Researcher, 30, 23-28. doi:10.3102/0013189X030003023.

Spillane, J. P., Halverson, R., \& Diamond, J. B. (2004). Towards a theory of leadership practice: A distributed perspective. Journal of Curriculum Studies, 36, 3-34. doi:10.1080/0022027032000106726.

Timperley, H. S. (2005). Distributed leadership: Developing theory from practice. Journal of Curriculum Studies, 37, 395-420.

Wallace, M. (2001). Sharing leadership of schools through teamwork: A justifiable risk? Educational Management and Administration, 29 (2), 153-167.

Weiss, C. H., \& Cambone, J. (1994). Principals, shared decision making, and school reform. In The Jossey-Bass reader on educational leadership (pp. 366-389). San Francisco: Jossey Bass

Williams, C. G. (2011). Distributed leadership in South African schools: Possibilities and constraints. South African Journal of Education, 31: 190-200. 
Yukl, G. (1999). An evaluation of conceptual weaknesses in transformational and charismatic leadership theories. Leadership Quarterly, 10(2): 285-305. 
DANDY G. DAMPSON

Dandy Dampson holds a PhD from the University of Northampton, UK, in Educational Administration, Management and School leadership. He is currently a senior lecturer and the head of department of Psychology and Education at the University of Education, Winneba, Ghana. He has published over 16 articles local and international. 